\title{
THE DYNAMISM OF ENGLISH AS A GLOBAL LANGUAGE IN POST-GENOCIDE RWANDA
}

\author{
Jacques Lwaboshi Kayigema \\ Department of African Languages, University of South Africa \\ Email: jacqueskayigema@yahoo.com \\ Davie E. Mutasa \\ Department of African Languages, University of South Africa \\ Email : mutasde@unisa.ac.za
}

APA Citation: Kayigema, J. L., \& Mutasa, D. E. (2017). The dynamism of English as a global language in postgenocide rwanda. Indonesian EFL Journal, 3(1), 101- 110

Abstract: English, as global language, has had great influence over most languages of the world for nearly two centuries now. The expansion of English is no exception in Rwanda, though. For the last two decades, the importance of English has been felt in the day to day activities of Rwanda. English became a third official language in Rwanda just after the 1994 genocide and a compulsory language of instruction since January 2009. This paper discusses the use of English in post-genocide Rwanda and its impact on French, over a borrowing one, Kinyarwanda and French. English has risen sharply for the last two decades because of the will of the Rwandan government to find ways of communicating with the external world in a more powerful language, English, than the previously predominant one, French. It also highlights major domains where English speaks of its strength and the factors that led to the spread of English.

\section{INTRODUCTION}

Kinyarwanda is primarily the language spoken in Rwanda, which is a land-locked country on the African continent, $26.338 \mathrm{sq}$ $\mathrm{km}$ in size, and with a population of 11.689 .696 (July 2012 estimate) people. Rwanda is thus the most populated country in Africa with a population density of almost 420 people per sq $\mathrm{km}$. The country is very often given the title 'Land of a Thousand Hills,' simply because of its fertile and hilly terrain. With an average altitude of $1.600 \mathrm{~m}$ above sea level, the country enjoys a temperate climate.

Currently, Rwanda has three official languages: Kinyarwanda, French, and English. In addition, in view of the cultural, social, commercial, and political ties that exist between Rwanda and East African countries (Kenya, Tanzania, Uganda), Kiswahili too has been used in commercial centres as a lingua franca, and on the nationally broadcast radio.

Before Belgians introduced French into primary school in 1929, Kiswahili was used to serve as a language of communication in the colonial administration. Most Belgian colonial masters and missionaries of all denominations were using Kiswahili.

French is more widely spoken and more predominant than English and Kiswahili. It has been an official language since 1962 , during which time the first constitutional law of the Republic of Rwanda was voted (24 November 1962). Article 69 of the decree of the Ministry of Education of 27 August 1966 stipulates that the language of instruction for primary school education is Kinyarwanda, but that the Minister can authorise the use of another language.

As for languages of instruction in secondary education, article 80 of the same decree gives the Minister of Education the authorization of introducing another official language. It stipulates that Kinyarwanda and French are the official languages, but that the Minister can authorise the use of another language. 
Before 1994 English was not used at primary school. At secondary school it was studied like any other subjects and at the tertiary level it could be studied among other subjects or as a major in the department of languages and literature. The weekly class load for English was based on a particular line or section of study. The number of hours per week ranged between 2 and 4. On the other hand, French was the language of instruction at secondary level.

English became a third official language just after the 1994 genocide. Article 5 of the current Rwandan constitution law stipulates that 'the national language is Kinyarwanda and that the official languages are Kinyarwanda, French and English' (Official Journal, 2003). It is in this perspective that since January 2009, English has been adopted as a medium language of instruction at all levels.

More than 24.000 Rwandans speak English. Rwanda is one of the territories where English is spoken as an "official (institutionalized) second language (L2) in the fields such as government, law, and education" (Jenkins, 2003, p. 2). English is gaining more influence over French. The motivation of using a prestigious language like English is highly noticed in every activity of life. Crystal (2003, p. 67) notes that "new political decisions on the matter continue to be made: for example, Rwanda gave English official status in 1996." This policy will make linguists have special consideration for Rwanda, unlike its neighbour, Burundi, which is not represented in the list of speakers of English in countries where the language has had special relevance. In fact, Burundi shares almost entirely the same historical and political background.

Kinyarwanda is not only spoken in Rwanda, though. It is also widely spoken across politically agreed upon borders in neighbouring countries, such as the eastern Congo: northern Kivu (Rutshuru, Masisi) and southern Kivu (Uvira, Fizi, Mwenga, Moba). In addition it has spread across to western Uganda (where it is spoken by the Bafumbira tribe) and eastern Tanzania (where it is spoken by the Abanyakaragwe and Abaha tribes). In Burundi, the neighbour to the south, it is mutually intelligible with Kirundi; in a similar way Flemish is intelligible to the Dutch-speaking inhabitants of the Netherlands.

\section{Writing in English is Fashionable}

The subtitle above recalls Senghor's question "Why do we write in French?" "We write in French because French is a universal language," he answered (Ngugi, 2005, p. 32). However, in Rwanda the aim of writing in English is totally different.

The question as to know why today we prefer to write in English rather in other languages in order to express ideas more accurately, can be answered in the perspective of the supremacy of English. Unlike Senghor who wanted to tame the French language for cultural, political, and literary purposes, there is no leading literary figure in Rwanda who writes to promote English culturally, politically, or literarily, but rather people write English for lucrative and prestige ends.

In schools, English is taught because it is a global language for communication, scientific research, economy and commerce. However, outside the classroom, for example at home, parents and children use the vernacular language, Kinyarwanda, which makes it hard to practice English.

Asked why we teach French in Africa, Senghor (1993) answered the question starting with the definition of francophonie, which aims to spread French politics and culture.

La Francophonie, c'est cet humanisme intégral qui se tisse autour de la terre: cette symbiose des "énergies dormantes » de tous les continents, de toutes les races, qui se réveillent à leur chaleur complémentaire [...] le français est déjà enseigné comme langue nationale, langue officielle, langue de communication internationale ou, simplement, mais essentiellement, comme langue de culture. Si on introduit ou maintient l'enseignement du français en Afrique, si on l'y renforce, c'est, d'abord, pour des raisons politiques. Cependant, la principale raison de l'expansion du français hors de l'hexagone, de la naissance d'une Francophonie est d'ordre culturel. Francophonie is that integral humanism which weaves around the globe: that symbiosis of 
dormant energies of all the continents, all the races, which awake for the complementary warmth [...] French is already taught as a national language, an official language, a language of international communication or, simply, but essentially, as a language of culture. If teaching French in Africa is introduced or maintained, if it is reinforced there, it is first for political reasons. However, the major reason for French expansion outside the hexagone (France), the birth of Francophonie is cultural. (Senghor) in Diagonales, $\mathrm{N}^{\circ} 28$ (1993)

Unlike the French Academy which sets up rules on the use of French as far as spelling and pronunciation are concerned, there is no English Academy which regulates the use of English worldwide. There has not been any officially recognized institution to promote English. Probably the British Council has been doing this work but with not strict regulations on the spelling and the pronunciation of English. There is no such a thing as "Anglophonia". The Commonwealth organization has no aim to promote the expansion of English culturally and politically among member countries. There is no English Academy to regulate the use of English as far as grammar, spelling, and pronunciation are concerned. However, today's tendency is to write, especially where French and English cohabitate. Materials which are very often written in English include commercial advertisements (signs, posters, film strips, radio, and TV commercials), official reports, project proposals, academic transcripts, newspapers, catalogues, folders, and booklets.

\section{A New Form of English in Rwanda}

Varieties of languages very often result from the non-confirmity to the pronunciation model of the standard language. Although mistakes are part of learning process, they simply reveal a failure in language competence. Due to various forms of English worldwide in general, and nationwide in particular, the English spoken in Rwanda reflects interference from East African English, West African/Nigerian English, Indian English, American English, South African English, French, Kinyarwanda.
In addition to mistakes due to French and Kinyarwanda interference, varieties of English are also responsible for the mistakes which are very often made. Most mistakes occur in the area of phonology, orthography, syntax, and semantics. Because of the phonological perception and production, some mispronounced English words have become integrated loanwords in Kinyarwanda.

\section{English Name Changes from 1994 onward}

In Rwanda it is currently easier to count shops and commercial buildings with fewer names in French than in English because of the significance drop in French usage. From 1994 Rwandans find it more fashionable and prestigious to use a global language like English than French. The interest in this shift of name change triggered the motivation for researching on the rise and spread of English in Rwanda after the 1994 events. The sense of observation and curiosity of the use of the word 'house' on most names of shops, firms, and organizations challenges researchers in language contact and change. For example, a careful eye can read the following names with the word 'house' in them in the city of Kigali: Blue Star House, Centenary House, Prince House, City Plazza House, Ebenezer House, Mathias House, Rugigana House, Rubangura House, La Bonne Adresse House, Omega House, Promise House, Isaro House, Ituze House, Magnificat House, Nartzalus House, Soafa House, Iramiro House. In addition to names bearing the word 'house' in them, public and private establishments (schools, hotels, restaurants, pubs) have also adopted English identifications: Kigali Parents School, Green Hills Academy, Kicukiro College of Technology, Umutara Polytechnique, Foundation School, Sun City Hotel, Alfa Palace Hotel, Bloom Hotel, Kivu Sun Hotel, Peace Hotel, Greenland Hotel, Luxury Hotel. Names of organizations and state-run authorities have completely shifted from French to English. For example, one may read: Rwanda Environment Management Authority (REMA), Rwanda Revenue Authority (RAA), Rwanda Bureau of Standard (RBS), Rwanda Development Board (RDB), 
Rwanda Governance Board (RGB), Rwanda Defence Force (RDF), National Commission for Reconciliation (NCR). However, those organizations and state undertakings which existed before 1994 are still written in French: Magasins Généraux du Rwanda (MAGERWA), Usine de Textile au Rwanda (UTEXRWA), Société Nationale d'Assurance au Rwanda (SONARWA), Brasserie et Limonaderie du Rwanda BRALIRWA), Ciment du Rwanda (CIMERWA)

Everybody wants a change and something new. This phenomenon of name change is a paradigm shift. Not only names and styles of firms have changed after 1994 but also anthroponyms and names of persons. Today you will find that young people bear names such as Nice, Joy, Hope, Peace, Shalom, Bob, Jimmy, Jackson, Steve.

\section{Globalization as a major factor for the spread of English}

Most people see globalization as a major factor in the spread of English in Rwanda. Globalization creates free flow of information on the information highway which is dominated by English. Indeed the views of the respondents tally with those of Crystal (2003) in his book entitled English as a global language.

The spread of English in the world in general is the result of the first migrations of mother-tongue English speakers from England, Scotland and Ireland predominantly to North America, Australia, New Zealand and the establishment of British colonies in Africa, Asia, and Central America (Jenkins, 2003, p. 5).

Subsequently, the rise of English in Rwanda is linked to the position of English as a global language and it has been reinforced by the change of the regime whereby the repatriation of Rwandans who returned from exile in the neighbouring English speaking countries triggered the use of English in all the major domains of public and private sectors.

The increasing influence of English in Rwanda like in many other parts of the world makes people think that English is very likely to be a dominant language over other languages of the world for many years to come. With some reservations, Abdulla (2005, pp. 3-10) supports this view when he points out that English is a global language:

While English has become the Latin of the contemporary world, such a position, one can say in the light of historical experience, has always been precarious. Whether English will be unanimously accepted as the one unifying international language of the globe, whether it will share this role with one or more other languages or whether an artificial language will be adopted for that purpose is the question that sooner or later we will all be facing [...]. Still, one may well conclude, as a result of what has been discussed so far, and in spite of all the reservations expressed, that English is now ipso facto the uncontested international language. Without any prior agreement, or officially imposed policy, it has practically that status - in trade, science, tourism, and most importantly, in the educational system, through the world. The possibility of any other language, whether natural (Spanish) or Chinese or artificial (Esperanto) replacing it in the near future seems remote.

While in the above statement Abdulla is reserved as to whether English will remain the contemporary global language of the world as was Latin for more than seven centuries. Mufwene (2010, p. 57) thinks that "although English has become a global language geographically, it is not becoming a universal one, a fear mitigated by its speciation into so many varieties, some of which have already been disfranchised as separate languages, viz. creoles and pidgins.". In fact, Mufwene (2010, p. 57) wonders whether English is becoming as universal as Crystal and others who marvel on the globalization of English put it. He rather attributes the spread of English to the prescription of English as a second or foreign language in the secondary schools in most countries of the world:

So much has been published over the past decade about the extent to which world-wide globalization (...) has spread English into a "global language," i.e., one spoken all over the world. Much of this evolution can be attributed as much to the prescription of English as a second or foreign language in secondary schools of almost every country of the Outer and Expanding Circles today as to its usage as the primary lingua franca of business, 
navigation, science and technology, and academia (Mufwene, 2010, p. 57)

In the University of Chicago Chronicle, Mufwene quoted by Schonwald (2008) gives the example of the Democratic Republic of Congo, whereby French is not threatened by the global English but rather by Lingala: English is far from functioning as the vernacular of many parts of the world," he said. In Kinshasa, the capital of his native Congo, for instance, there is little economic incentive to learn English as a vernacular. There, the official language, French, is threatened not by English, but by Lingala, a contact-based Bantu language that has become increasingly popular. Many linguists focus on worldwide trends, which spread English as a lingua franca but don't recognize the dynamics of the local ecology of a language. "Language evolution is driven primarily by the interplay of local ecological factors, which are largely socio-economic," he said.

Crystal (2003, p. 67) supports the view that Rwanda has adopted the global English and attributes this move to the political decision. Rwanda is classified in the three concentric circles as developed by Kachru (1988). In pointing out the example of Rwanda which gave English official status in 1996 because of the new political decision, Crystal compares Rwanda to Burundi and apparently gives them the same status. He comments that "English is probably represented in Rwanda and Burundi in very comparable ways, but Rwanda is in the list (and Burundi is not) only because the former has (in 1996) made a political decision to give the language special status."

The status of English in both countries is totally different. Therefore the classification should be very clear. Burundi uses English simply as a foreign language, which has great importance for communication, whereas Rwanda uses it as an official language alongside Kinyarwanda and French. The context is different in both countries. Burundi did not find any sound reason to adopt English as an official language. However, after the 1994 genocide and the war, Rwanda had no other option. It had to accommodate Rwandans speaking the two international languages: English and French. Thus, Rwanda marked a significant step in leaving the expanding circle or extending circle to join the outer circle or the extended circle when it institutionalised English.

In Rwanda the expansion circle period of English is marked by the use of English as a mere foreign language. Although this period starts before 1996, during which time English was officially recognized by the Rwandan government, the researcher could say that the expansion period is located between 1962 and 1994. During this period English gradually spread in various areas such as education, agriculture, commerce, technology, communication and the press, just to mention the most influential ones. In 2009 the position of English was reinforced by adopting it as a language of instruction.

Education is the most influential domain which determines whether a language will be predominant in a given country or not. This is because all linguistic and scientific knowledge is acquired at school. The use of a language cannot be efficient unless teaching the language has taken place. At primary school English was neither used as a subject nor an instructional language.

\section{English as a language of learning and teaching}

Today learning English is very important because it offers better opportunities in communication and employment. The rise of English in Rwanda is an asset rather than a threat to Kinyarwanda because it connects Rwanda to the external world. However, it may lead to diminishing use and role of French and Kinyarwanda.

Before 1994 English was taught from the first to to the sixth year of secondary school. Of course, the number of class contact hours sometimes differed from one line to another. Language-based lines, commerce and accounting had more hours than other lines. At the National Office of Curricula Development there was a department in charge of English curriculum development. English curriculum developers were recruited among University graduates who had completed three to five years of university programme. However, some were 
not necessarily trained to teach English, nor develop curricula of English.

In addition to the formal education of English there were some organisations and embassies which offered English programmes to boost the level of English language proficiency for beginners, intermediate and advanced students. For example, in the early 1980s, the Information Service of the US Embassy in Kigali opened the English Language Teaching Centre to cater for civil servants and other people who did not have enough knowledge of English as working language. The centre also provided English language training to prepare individuals who wished to take some international tests like TOEFL or the Michigan Test to pursue their studies abroad. At tertiary level, the National University of Rwanda and other institutions of higher learning offered English as a major in the department of English. Most teachers of English were trained in local universities and institutions of higher learning. Some others were trained in the neighbouring countries (DRC, Kenya, Uganda, Tanzania, Burundi) where English programmes are offered at various levels. Exceptionally, some teachers of English were trained in the UK, the USA, and Canada.

Just after the war, with repatriated Rwandans from both French and Englishspeaking countries, there has been a great need for bilingual workers in post-war Rwanda. As a result, educational reforms have taken place. The 1996 Educational Reform adopted both French and English as medium languages for instruction and as subjects. Until 2008, from Primary One to Primary Three, where possible, French and English were taught as subjects, whereas from Primary Four to Primary Six, they were both subjects and languages of teaching other subjects, except Kinyarwanda. Today, English is a medium of instruction from Nursery to University. Besides this, short courses of English are offered by both public and private institutions to train French and Kinyarwanda speakers in English.

Of course, one may wonder which form of English Rwanda is very likely going to adopt. Everything will start from the class.
Owing to the training in different countries, teachers are very likely to bring in various accents of English which will be passed onto students. Thus, among Rwandan English speakers or bilingual speakers of English and French it is very likely to hear Ugandan English accent, South African English, British English, American English, Nigerian English, just to name a few.

\section{English in the media}

"In the novel, the media are at the centre of everyone's life - the press, radio, advertising, and especially television. Even the 'hint of a nuance' can make a difference... The English language has been an important medium of the press for nearly 400 years" (Crystal, 2003, p. 91).

People listen to the news broadcast, watch TV programmes, and read newspapers in English because they want to improve their level of performance in it and because of their positive attitude towards English. Although English does not dominate the media now, this is a sign of motivation for people who are eager to improve their English performance.

The state runs the largest radio and television stations. On the national television, Rwanda Television (RTV), and radio broadcast, news broadcast programmes in English are given equal weight as in Kinyarwanda and French. After all, these are the three official languages recognized by the Rwandan constitution. English is not dominating in the media, though. Kinyarwanda is the most dominant language in the media. The media are taking the lead in today's globalization, and in view of the pace English is making, a global language is very likely to dominate the media in the near future.

Most people do not have access to television because it is limited to urban areas. Kinyarwanda dominates on the national television broadcast. However, with private companies, such as Star Africa Media, branded Star Times, a Chinese digital television company operating a pay television service with 35000 registered users, English is the dominating language. Of the 44 channels, 5 broadcast entirely in French, 2 in Kinyarwanda, English and French. Obviously, 
this has a great impact on the role of other languages in media.

As for the radio broadcast, there are more than 30 radio stations operating in Rwanda now and each of them has one or more English programmes. These include Radio Rwanda, Radio 10, Flash FM, Contact FM, City Radio, Radio Isango Star, Radio Maria, Radio Izuba, Radio Salus, Amazing Grace Radio, Umucyo Community Radio, Voice of Hope, VOA, DW, RFI, BBC. Up to 70 local newspapers are written in Kinyarwanda, 5 in English (with the weekly leading, The New Times), and 3 in French. Of course, the national language, Kinyarwanda, occupies the first position, followed by English and then French.

\section{Impact of English: code-switching and borrowing}

In a bilingual context, code-switching is very common. This impacts on the structure of Kinyarwanda. In Rwanda, it is very common to hear a bilingual speaker using French and English words without altering the grammatical structure, the morphological and phonological aspects of a foreign word, a phrase, or a sentence.

Frequently used code-switches from French may include simple words such as donc, 'so'; vraiment, 'truly'; responsable, 'responsible'; sérieux, 'serious'; grave 'serious'; comment (ça $v a)$ ?, 'how are you (doing)?'; ça va? , 'Is it okay?'; Ni dix heures, 'It is 10 o'clock'.

The level of code-switching varies from one bilingual to another. One may switch codes at the level of:

(1) words, for example, Lundi uzanyoherereze call: "Give me a call on Monday".

(2) tags, for example, He sings well, n'est-ce pas? : "He sings well, doesn't he?".

(3) clause or sentence (intersentential switching). For example, je voudrais te parler (I would like to talk to you), come quickly.

However, it may or not be intentional. For example, during some simultaneous translation activities, the researcher has experienced a situation whereby an interpreter, from time to time, could switch from English to French while he was translating from French into English. He would not be aware of his error until the public reacted to his unintentional switching. This would create a funny situation. In fact, Rwandan monolinguals think their language has been diluted.

Following the current sociolinguistic situation in Rwanda, whereby most people have various backgrounds because they lived in a multilingual community, one may hear, for example, the following code-switches:

\section{Tokomonana lobi, ariko uzibuke cya gitabo} (Lingala-Kinyarwanda):

'We shall meet tomorrow, but remember to bring that book'.

Lundi uzanyohereze call (French-

Kinyarwanda-English): 'Call me on Monday'. Urebe ako gaka, mwanawafe (KinyarwandaKiganda): 'Look after that cow, our child!' Ndagutegetse ngo Toka Shetani (Kinyarwanda-Kiswahili): 'I command you: Go way, Satan!'

Bagiye, je le sais bien! (Kinyaruanda-French): 'They have gone, I know it well'.

Concerning code-switching, (Field, 1998, p. 241) explains that it involves running syntactic analyses. In production, it involves the establishment of entry and exit points in the linear speech stream, so-called switch points at which the language in use is deactivated to an extent.

In today's bilingual context in Rwanda, a bilingual speaker of English and Kinyarwanda may frequently use codeswitches such as: so, actually, anyway, Okay, now, sharp.

The phenomenon of code-mixing is very common when bilingual speakers are making speeches or conversing with the audience they think understands the languages they are using. The word which comes more easily than another is immediately uttered. Some bilinguals make efforts not to mix the codes. However, this will depend upon one's language competence.

Since language is a vehicle of the culture of a given nation, English has bequeathed to Kinyarwanda words and elements of the western culture. The motivation for borrowing which must readily 
come to mind is need. If the speakers of a given language take over new cultural items, new technical, religious concepts, or references to foreign locations, fauna, flora, there obviously is a need for vocabulary to express these concepts or references. In addition to the need, the speaker of A may have a prestige motive, especially when speaker B is more powerful economically, politically, religiously, and technologically.

For example, the speaker of

Kinyarwanda has borrowed many religious terminologies not because he did not have any religion and beliefs, but simply because he was persuaded by the western religious clergy that his religion was heathenish. That is why he quickly forsook 'indigenous names' and adopted 'Christian names', which were in fact from 'Hebrew and western names'.

\section{English and the young generation and the impact on the future role of Kinyarwanda}

English is viewed by the young

generation as a language of hope, empowerment, opportunities, openness and prestige. Young Rwandans are eager to use English at school, in various English language centres, sports, cinema, music and other daily activities which attract the youth.

Young generation users of English include young artists, musicians, football players, drivers, and civil servants. They want to use English in their entertainment because they hope English will help them become successful in their occupations. The media help the youth attain the goals of practicing English when they are present their talents on the radio or television. Crystal (2003, p. 101) observes that "radio sets around the world hourly testify to the dominance of English in the popular music scene today." He adds that "many people make their first contact with English in this way."

Most people have expressed their enthusiasm in welcoming English as an asset to the existing benefits of French and Kinyarwanda. They do not consider English as a threat at all. On the contrary, they would like the country to develop into a bilingual system of English and French, in addition to their lingua franca, Kinyarwanda.
Youth find the rise and spread of English in Rwanda as an asset rather than being a threat to Kinyarwanda and French. Very few people think English may be a threat because English may be a contributing factor to forget existing official languages. The proponents of English maintain that it facilitates communication among people who speak it.

\section{CONCLUSION}

This paper has established that the rise and the spread of English in Rwanda is linked first to the return and repatriation from exile in the neighbouring English-speaking countries of sons and daughters of Rwanda who had fled the 1960s events which caused many a Rwandan to flee the country. It is also enshrined in the framework of globalization which makes Rwanda open to the external world and therefore complies with globalization in order to communicate and cooperate with great powers and the international community at large.

Globalization is a major factor for the spread of English from the time of the British Empire and the supremacy of the United States of America until the present time. Besides this, English will continue to be an international language for the foreseeable future even if some major languages of the world like French, Spanish and the Mandarin Chinese are widely spoken in the world.

With regard to learning and teaching a foreign language, English takes the lead in schools. It is the medium of instruction which no one dares to oppose. Everybody agrees that today English is needed in all major areas. After all, most countries of the world have adopted it as the language of instruction. Beside national and official languages, English occupies a very important position in learning and teaching other subjects.

This study has indicated that a new form of English is developing in Rwanda as it is in other parts of the world. World Englishes is currently a hot topic of linguistic research and the variety of English in Rwanda which results from the influence of Kinyarwanda, French and East African English will not escape from the eye of the researchers. Based on the mistakes of pronunciation, grammar, 
spelling and vocabulary which are encountered in Rwanda, another form of English will appear, unless there is an academy of English which would curtail the wrong usage of the English language worldwide.

With regard to the presence of English in major domains, this study established that English is ever dominant in the areas of education, the media, commerce, banks and banking, information communication, technology, science, army and diplomacy. You feel the presence of English in the text materials, teaching materials and visual aids, newspapers, computers, laboratory and army equipment, and the international diplomacy.

The aspect of bilingualism has been highlighted in this study. Code-switching and borrowing are a reality in a multilingual community. The degree of performance depends on how the individual copes with this reality of language contact. Owing to the educational system and the need in training bilingual speakers of English and French, both languages will continue to cohabitate in Rwanda alongside Kinyarwanda.

The study has concluded that the name change and the display of English from 1994 onward on new buildings, styles, firms, organizations and institutions is a paradigm shift. People want to use a fashionable language because it sounds scientific, intellectual and witty.

As far as the impact of English on the role of Kinyarwanda and the attitudes of people towards other languages, the study has indicated that the young generation considers English as a language of hope because of the opportunities to communicate and pursue studies. It does not threaten Kinyarwanda at all because the latter is a lingua franca and is widely spoken in families, schools, offices and elsewhere in Rwanda, and across the borders.

\section{REFERENCES}

Abdulla, A. D. (2005). Globalism and the universal language. English Today, 82(2), 3-10. Cambridge: Cambridge University Press.

Crystal, D. (2003). English as a global language ( $\left.{ }^{\text {nd }} e d.\right)$. Cambridge: Cambridge University Press.

Jenkins, J. (2003). World Englishes. London: Routledge

Kachru, B. (1988). The sacred cows of English. English Today, 16, 3-8. Cambridge: Cambridge University Press.

Mufwene, S. (2010). Globalization and the spread of English: What does it mean to be Anglophone? English Today, 26, 57-59. Cambridge: Cambridge University Press.

Senghor, L.S. (1993). Pourquoi enseigner le français en Afrique. Diagonales 28, 4-5. Paris: EDICEF. 


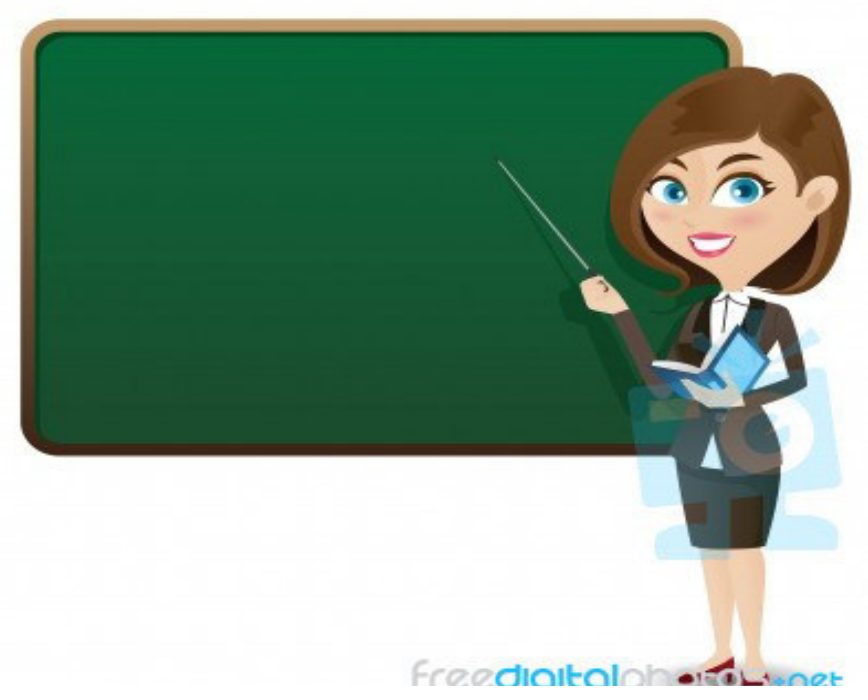

\section{Teacher}

A teacher asks her class, "If there are 5 birds sitting on a fence and you shoot one of them, how many will be left?" She calls on little Johnny. He replies, "None, they all fly away with the first gun shot" The teacher replies, "The correct answer is 4, but I like your thinking." Then, Little Johnny says "I have a question for YOU. There are three women sitting on a bench having ice cream: One is delicately licking the sides of the triple scoop of ice cream. The second is gobbling down the top and sucking the cone. The third is biting off the top of the ice cream. Which one is married?" The teacher, blushing a great deal, replied "Well I suppose the one that's gobbled down the top and sucked the cone" To which Little Johnny replied, "The correct answer is the one with the wedding ring on, but I like your thinking."

(Source: http://www.study-express.ru/humour/funny-stories.shtml, picture: www.google.co.id) 